\title{
Sac Malzeme Üretiminde Hata Türleri ve Etkileri Analizi
}

\author{
Batuhan Özakın ${ }^{1 *}$ \\ 1* Samsun Üniversitesi, Kavak Meslek Yüksekokulu, Motorlu Araçlar ve Ulaştırma Teknolojileri Bölümü, Samsun, Türkiye, (ORCID: 0000-0003-1754-949X), \\ batuhan.ozakin@samsun.edu.tr
}

(1st International Conference on Applied Engineering and Natural Sciences ICAENS 2021, November 1-3, 2021)

(DOI: $10.31590 /$ ejosat.1013679)

\begin{abstract}
ATIF/REFERENCE: Özakın, B. (2021). Sac Malzeme Üretiminde Hata Türleri ve Etkileri Analizi. Avrupa Bilim ve Teknoloji Dergisi, (28), 1204-1209.

Öz

Sac malzemeler genellikle soğuk haddeleme yöntemiyle üretilen yassı ürünlerdir ve birçok endüstride yoğun olarak kullanılmaktadır. Üretim sürecinde üründe meydana gelen hatalar birtakım sorunlara yol açmaktadır ve hatalı ürünün kullanımı yine birtakım olumsuzluklara sebebiyet vermektedir. Dolayısıyla üretim sürecinde hataların giderilmesine yönelik birtakım önlemler alınması gerekmektedir. Bu amaç doğrultusunda Hata Türleri ve Etkileri Analizi (HTEA; FMEA) yöntemi oldukça yaygın olarak kullanılmaktadır. Bu çalışmada soğuk haddeleme yöntemiyle üretilen sac malzemelerde üretim sürecinden kaynaklı meydana gelebilen ürün hataları belirlenmiş ve bu hatalara yönelik HTEA yöntemi kullanılarak risk öncelik sayıları (RÖS) tespit edilmiştir. Üretim sürecinde yüksek riske sahip (RÖS>100) hataların oluşmasını engellemek veya azaltabilmek amacıyla alınması gereken önlemlere yönelik birtakım önerilerde bulunulmuştur.
\end{abstract}

Anahtar Kelimeler: Soğuk Haddeleme, Sac Malzemeler, Hata Türleri ve Etkileri Analizi, Risk Öncelik Sayısı, Düzeltici Faaliyetler.

\section{Failure Modes and Effect Analysis in Sheet Metal Manufacturing}

\begin{abstract}
Sheet materials are generally flat products produced by cold rolling and are used extensively in many industries. Defects in the product during the manufacturing process cause some problems and the use of the defect product also causes some negativities. Therefore, some measures should be taken to eliminate defects in the manufacturing process. For this purpose, Failure Modes and Effects Analysis (FMEA) method is widely used. In this study, product defects that may occur due to the manufacturing process in sheet materials produced by cold rolling method were determined and risk priority numbers (RPN) were determined by using the FMEA method for these defects. In order to prevent or reduce the occurrence of high-risk (RPN $>100$ ) defects in the manufacturing process, some suggestions have been made for the precautions to be taken.
\end{abstract}

Keywords: Cold Rolling, Sheet Materials, Failure Modes and Effects Analysis, Risk Priority Number, Corrective Actions.

\footnotetext{
*Sorumlu Yazar: batuhan.ozakin@samsun.edu.tr
} 


\section{Giriş}

Sac malzemeler, kalınlıkları 0.2-2.0 mm arasında değişen ve soğuk haddeleme yöntemiyle üretilen yassı ürünlerdir (Erdemir, 2021). Soğuk haddelenmiş yassı ürünler otomotiv, havacılık, makine, konstrüksiyon vb. birçok endüstride yoğun olarak kullanılmaktadır (Sharma ve Yadava, 2018). İmalat sürecinde üretimi gerçekleştirilen üründe meydana gelen hatalar, ürün kalitesi açısından sorunlar oluşturmakta ve hatalı ürünün kullanılması zaman, işgücü ve kaynak vb. kayıpların meydana gelmesine sebebiyet vermektedir. Dolayısıyla imalat sürecinde hataya sebebiyet veren unsurların belirlenmesi, öncelik sırasına konulması ve bu unsurların süreç içerisinde çözümüne yönelik birtakım önlemlerin alınması gerekmektedir. $\mathrm{Bu}$ amaç doğrultusunda çoğunlukla kolay ve etkili çözümler sunan, sıklıkla kullanılan Hata Türleri ve Etkileri Analizi (HTEA) yönteminin kullanımı oldukça yaygındır (Şimşir vd., 2018). HTEA (FMEA: Failure Modes and Effect Analysis) yöntemi, imalat sürecinden elde edilen ürünün müşteriye sunulmadan önce süreçten kaynaklı hatalarının tanımlanması, belirlenmesi ve önlenmesi için başta kullanılan bir yöntemdir ve böylece imalat sürecindeki kayıpları en aza indirerek ürünün kalitesinde artışa yol açar ve müşteri memnuniyetinin artmasina sebep olur (Stamatis, 2003; Nguye vd., 2018; Wu vd., 2021). Literatürde HTEA tekniğini kullanarak üründe meydana gelen hata türlerini ve etkilerini analiz eden birçok çalışmaya ulaşılabilir. Vinodh ve Santosh (2012), bir otomotiv yaprak yayı (makas) üretim organizasyonuna HTEA yönteminin uygulamasını yapmışlardır. Çalışmada, tasarımda iyileştirmeye yol açan eylemler tespit edilmiş ve bu eylemlerin takibi sonucunda makasların kalitesinde iyileşme olduğu belirlenmiştir. Mhetre ve Dhake (2012), hassas pres parçaları imalat endüstrisindeki hataları azaltmak, geliştirme süresini kısaltmak ve ürün güvenilirliğini artırmak amacıyla Ishikava diyagramı ile HTEA yöntemlerini uygulamışlardır. Potansiyel riskler ve mevcut riskleri tanımlamışlardır. Olası risklere en kısa sürede alınması gereken bazı önlemler önermişlerdir. Parsana ve Patel (2014) yaptıkları çalışmada, silindir kapağı üretim sürecinde HTEA yöntemiyle mevcut ve potansiyel hataları belirlemeyi ve ortadan kaldırmayı amaçlamışlardır. Ayrıca silindir kapağı üretim süreçlerinin verimliliğini ve etkinliğini iyileştirmeye ve müşteri memnuniyetini artırmaya yardımcı olan potansiyel risklerden kaçınmak için mümkün olan en kısa sürede alınması gereken bazı eylemler önermişlerdir. Bu çalışma ile hem parasal zaman hem de kalite açısından endüstrinin kaybının önemli ölçüde azaltabileceği sonucuna varmışlardır. Suresh ve arkadaşları (2017), kızartma tavası üretim sürecinde HTEA uygulamasını ele almışlardır. Hata türlerini belirleyerek her hata türü için risk öncelik sayılarını bulmuşlar ve yüksek riskli hata türlerini belirlemişlerdir. Şimşir ve arkadaşları (2018), haddehanede oluşan hata türlerini HTEA yöntemiyle bulup, risk öncelik sayılarını hesaplayarak olası hataları sıralamışlardır. Buldukları sıralamaları farklı hata türü ve analiz metotlarıyla karşılaştırmışlar ve farklı hata türü ve analiz metotlarının kullanılabilirliğini değerlendirmişlerdir. Kaya ve
Alaykıran (2019) yaptıkları çalışmada, döküm tekniği ile üretilen bir parçanın üretimine HTEA analizini uygulamışlardır. Döküm yöntemine ait üretim sürecini analiz etmişler ve hata türlerini belirlemişlerdir. Öncelikli olarak önlem alınması gereken hataları belirledikten sonra bu hatalara düzeltici ve önleyici eylemler önermişler ve alınan önlemler sonrasında hatanın oluşup oluşmadığını izlemişlerdir. Önlemler sonrasında yapılan faaliyetler doğrultusunda hata türleri üzerinde yaklaşık olarak \% 50 oranında iyileşme olduğunu gözlemlemişlerdir. Dwianda (2021), CNC freze makinelerinde HTEA tekniğini kullanarak pnömatik sistemlerinin performansını iyileştirmek için hataların türlerini belirleyerek hataları önlemeye yönelik birtakım öneriler sunmuştur. Çalışmanın sonucunda pnömatik sistemde en kritik riskin valf bileşeninde kaçak olduğunu ve bu risk için en iyi iyileştirmenin, bakım prosedürlerini üreticinin belirttiği doğrultuda izlemenin optimum sonuç olacağını önermiştir. Literatürde soğuk haddeleme ile üretilen sac malzemelerin üretim sürecine yönelik bir çalışmanın gerçekleştirilmediği görülmüş ve bu türden bir imalat sürecinde hata türleri ve etkileri analizi ile bir uygulama yapılmasının literatüre katkı sağlayabileceği öngörülmektedir.

$\mathrm{Bu}$ çalışmada soğuk haddeleme yöntemiyle üretilen sac malzemelerde üretim sürecinden kaynaklı meydana gelebilen ürün hataları belirlenmiş ve bu hatalara yönelik HTEA yöntemi kullanılarak risk öncelik sayıları (RÖS) tespit edilmiştir. Üretim sürecinde yüksek riske sahip (RÖS>100) hataların oluşmasını engellemek veya azaltabilmek amacıyla alınması gereken önlemlere yönelik birtakım önerilerde bulunulmuştur.

\section{Sac Malzeme Üretim Süreci}

S1cak haddeleme yöntemiyle üretilen levha veya şerit malzeme yüzeyinde birtakım istenmeyen kalıntılar, asitleme hattında (dekapaj) giderildikten sonra sıcak haddelemeye göre daha az ezme miktarıyla soğuk haddeleme işlemine tabi tutulur ardından deformasyon sertleşmesinin (pekleşme) etkilerini azaltmak üzere tavlanır. Tavlanan yassı ürün daha sonra müşteri tarafindan istenilen yüzeyin elde edilmesi için temper haddeleme işleminden geçirilir. Temper haddeden geçen yassı ürün direkt kullanılabileceği gibi korozyon etkilerinin yoğun olacağ uygulamalarda yüzeylerine birtakım kaplamalar (çinko, krom, kalay, alüminyum vb.) ile kaplanır. Son olarak yassı ürün dilimleme işlemine tabi tutulur ve birtakım kontroller (boyut, yüzey, kalınlık vb.) sonrasında paketlenerek piyasaya arz olunur (Değirmenci, 2006; Özakın ve Kurgan, 2019; Özakın, 2021). Şekil 1.a'da sac malzemelerin soğuk haddeleme imalat süreci gösterilmektedir. Soğuk haddeleme ile sac malzemelerin üretiminde şerit veya levha şeklindeki iş parçası, kalınlık yönünde iki döner merdane arasında sıkıştırılarak kalınlığının azaltılması esasına dayanır (Şekil 1.b). Dönen merdaneler şerit veya levha şeklindeki iş parçasını boşluğa çeker ve sıkıştırır. Nihai ürün sac şeklindedir (TI Strip, 2021). 


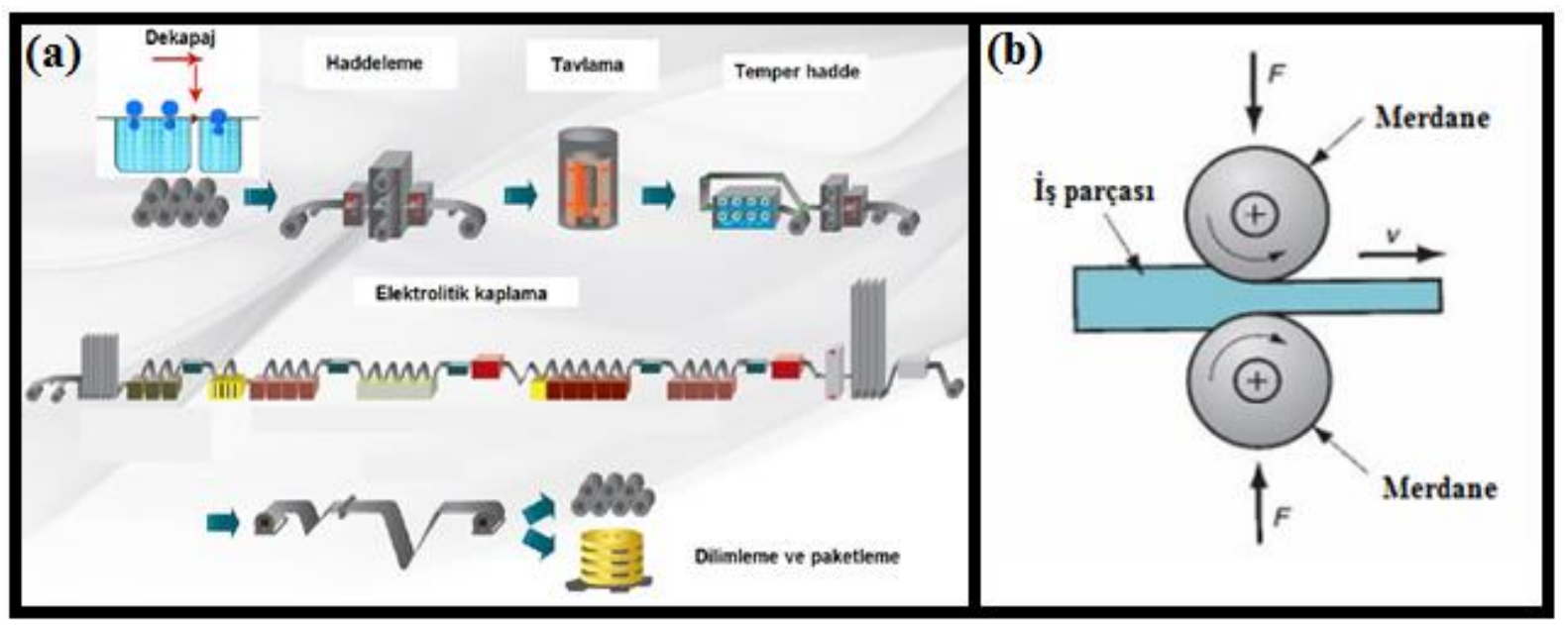

Şekil 1. a) Sac malzemelerin soğuk haddeleme imalat süreci (TI Strip, 2021), (b) Haddeleme yöntemiyle sac malzeme üretimi (Groover, 2020)

\section{Hata Türleri ve Etkileri Analizi}

Hata Türleri ve Etkileri Analizi (HTEA; FMEA), sistemlerde, tasarımlarda, süreçlerde ve hizmetlerde meydana gelen hataları ortaya çıkmadan önce, ortadan kaldırmak veya bunlarla ilişkili riski en aza indirmek amacıyla olası arıza türlerini belirlemek ve önceliklendirmek için yaygın olarak kullanılan bir mühendislik tekniğidir. HTEA, risk değerlendirme çalışmalarını desteklemek için tümevarım şeklinde bir yaklaşımdır ve HTEA'nın ilkesi, sistem boyunca potansiyel tehlikeleri belirlemek ve gerekli düzeltici eylemlere veya stratejilere öncelik vermektir. Kritiklik analizi için kullanıldığında, hata türleri ve etkileri yöntemi tercih edilir. Müşteri taleplerinin zamanında karşılanabilmesi için çeşitli mekanik proseslerin iyileştirilmesi gerekir ve böyle etkin bir analizin yapılması şarttır (Salvi ve Jindal, 2017). Çeşitli HTEA türleri (tasarım, üretim süreci, ekipman, sistem) ve farklı

$$
\text { Risk Öncelik Sayısı }(\text { RÖS })=\text { Şiddet }(S ̧) \times \text { Ortaya Çıkma }(0) \times \operatorname{Saptama~}(S)
$$

RÖS'nın düşük olması veya alınan önlemler ile düşürülmesi, hatanın önlenmesi, verimin artırılması ve rekabet şartlarının iyileşmesini gösterir. Denklemde RÖS'nın bileşenleri olan şiddet, ortaya çıkma ve saptama faktörleri, Tablo 1'de verilmiştir ve bahsedilen faktörler 1'den 10'a kadar sıralanmıştır. Bir risk için 10 puan, şiddet açısından çok tehlikeli olma (uyarısız tehlikeli), uygulamalar (donanımdan yazılıma) için olmasına rağmen, bu yaklaşımın temel amacı, olası sorunların erken tanımlanmasını desteklemek ve kazalar meydana gelmeden önce bunları ele almaktır (Colli, 2015).

HTEA, değerlendirmenin hâlihazırda yapıldığı kapsamda olası riskleri mümkün olduğu kadar belirlemeye çalışır ve şiddetine (Ş), ortaya çıkmasına $(\mathrm{O})$ ve saptanmasına (S) göre puanlanır. Aslında HTEA yöntemi, problemler ortaya çıktıktan sonra bir uygulama değil, olay öncesi bir işlem olarak planlanmıştır. Çoğu durumda bir sorunla karşılaşıldığında, sorunu ortadan kaldırmak için düzeltici eylemler tanımlamak mümkündür. HTEA yönteminde hatanın türü puanlanırken şiddet, ortaya çıkma ve saptanma olmak üzere üç faktörün çarpılmasından risk öncelik numarası (RÖS) adı verilen bir puan oluşturulur (Denklem 1).

ortaya çıkma açısından kesin oluşum (başarısızlık neredeyse kaçınılmazdır) ve saptanma açısından algılanamayan risk (mutlak belirsizlik) anlamına gelmektedir (Yousefi vd., 2018). Birçok kuruluşun benimsemiş olduğu ve RÖS değerinin 100'den büyük olduğu hatalar düzeltici önlem alınması gereken, risk taşıyan hatalar olarak kabul edilirler (Sönmez ve Unğan, 2016).

Tablo 1. RÖS bileşenleri olan şiddet, ortaya çıkma ve saptama faktörleri (Pillay ve Wang, 2003; Sönmez ve Unğan, 2016; Vinodh ve Santosh, 2012; Yousefi vd., 2018)

\begin{tabular}{|c|c|c|c|}
\hline Derece & Şiddet (Ş) & Ortaya Çıkma (O) & Saptama (S) \\
\hline 10 & Uyarısız tehlikeli & \multirow{2}{*}{ Çok yüksek } & Hemen hemen imkânsız \\
\hline 9 & Uyarılı tehlikeli & & Çok zor \\
\hline 8 & Çok yüksek & \multirow{2}{*}{ Yüksek } & Zor \\
\hline 7 & Yüksek & & Çok düşük \\
\hline 6 & Orta & \multirow{3}{*}{ Orta } & Düşük \\
\hline 5 & Düşük & & Orta \\
\hline 4 & Çok düşük & & Ortadan yüksek \\
\hline 3 & Önemsiz & \multirow{2}{*}{ Düşük } & Yüksek \\
\hline 2 & Çok önemsiz & & Çok yüksek \\
\hline 1 & Hata yok & Yok & Hemen hemen kesin \\
\hline
\end{tabular}




\section{4. Üretim Sürecine HTEA Uygulaması}

$\mathrm{Bu}$ çalışmada soğuk haddeleme yöntemiyle üretilen sac malzemelerde üretim sürecinden kaynaklı meydana gelebilen ürün hataları araştırılmıştır. Belirlenen hatalar üründe kayıplara, üretimin aksamasına bazen de üretimin durmasına sebebiyet veren türden olabilmektedir. Dolayısıyla sonuç olarak üretim sürecinde ürün meydana gelen hatalar, ürün kalitesinin azalmasına sebebiyet vererek müşteri memnuniyetsizliğine yol açabilmektedir. Üründe meydana gelen hatalar; literatür kaynakları, internet kaynakları ve sac malzeme üreticilerinden elde edilen bilgiler doğrultusunda elde edilmiştir (Andrei vd., 2010; Anita ve Singh, 2018; Steel JRV, 2021). Sac malzeme üretim sürecinde, üründe meydana gelen 19 adet hata belirlenmiştir. Bu hatalar şu şekildedir:

1. Kenar çatlakları: Sac malzemenin kalınlık kesiti boyunca meydana gelen belirgin çatlama veya kirilmalardir.

2. Merdane izleri: Sacın uzunluğu boyunca dağılmış noktalar, pullar veya şerit şeklinde çıkıntı ve çukurlardır.

3. Boyuna çatlaklar: Haddeleme yönü boyunca haddelenmiş parçanın yüzeyinde farklı uzunluk ve derinlikte çatlaklardır.

4. Enine çatlaklar: Haddeleme yönüne dik yönde $M$ veya $\mathrm{Z}$ şeklinde, haddelenmiş parça yüzeyinde düzensiz çatlaklardır.

5. Katlanma, kıvrulma: Genellikle sac malzemenin bitişinde meydana gelen kırışıklıklara benzer hatalardır.

6. Çizikler, oyuklar: Sac malzeme yüzeyinde mekanik (çarpma, düşme, sürtünme vb.) etkilerden dolayı meydana gelen hasarlardır.

7. Katlanmış kenarlar: Kenar kalınlaşması, kıvrılması veya mekanik hasar şeklinde bir hata türüdür.
8. Katlanmalar: Haddeleme yönüne dik veya çapraz genişlik boyunca meydana gelen kıvrılma veya bükülme şeklindedir.

9. Gevşek bobinler: Sarılan bobinler arasında büyük boşluk veya gevşeklik bulunmaktadır.

10. Dă̆ınık desen görünümü̈: Dekapaj sonrası yüzeyde dağınık parlaklıklarda desen oluşumu şeklindedir.

11. Yara izleri: Depolamadan kaynaklı malzeme yüzeyinde baskı șeklinde izlerdir.

12. Paslanma: Hava, su vb. belirli ortamlarda yüzey oksidasyonu sonucunda meydana gelen hatalardır.

13. Bobin düzleşmesi: Sarılı sac bobini elips şeklinde görünür ve yere temas eden kısmı düzleşme eğilimindedir.

14. Az miktarda dekapaj (asitleme): Asitle yıkanmamış veya az yıkanmış sac yüzeyinde siyah renkli oksit tabakası bulunmaktadır.

15. Çok miktarda dekapaj (asitleme): Asitle çok yıkanma yapıldığında gümüş beyazı görünüm ortada kalkar ve yüzeyde koyu siyah renk oluşumu meydana gelir.

16. Sac bobininin kenarlarının fazla veya eksik etli olması: Bobin kenarı, kesim sonrasında kötü kesim koşullarından dolayı normal ölçüsünden uzun veya kisadır.

17. Dalgalılık: Sac hadde yönü boyunca dalgalı bir görünüm sergiler.

18. Taşlama izleri: Haddeleme yönü boyunca merdanenin sac yüzeyinde düzenli şerit şeklinde bıraktığı izlerdir.

19. Siyah bant: Hadde yönü doğrultusunda ve sac genişliğinin bir kısmında siyah renkli bir film tabaka uzunlamasına dağılır.

Yukarıda soğuk haddeleme ile sac malzeme üretim sürecinde olası hata türleri belirlenmiştir. $\mathrm{Bu}$ çalışma boyunca belirlenen ürün hataları doğrultusunda izlenen HTEA sürecine ait akış diyagramı Şekil 2'de verilmektedir.

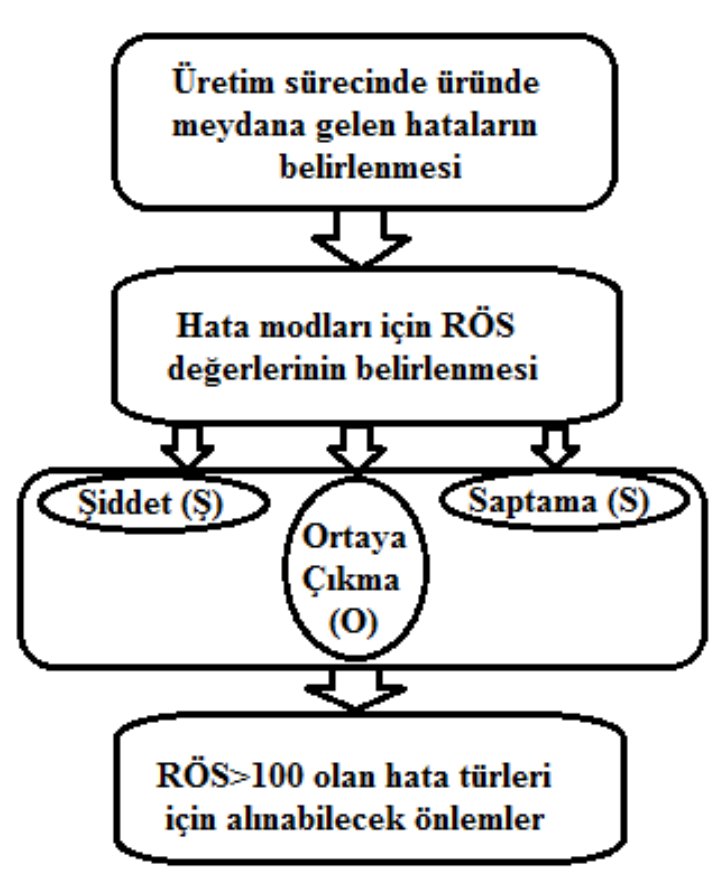

Şekil 2. HTEA sürecine ait akış diyagramı 
Soğuk haddeleme ile sac malzeme üretim sürecinde üründe meydana gelen hatalar belirlenmiştir. $\mathrm{Bu}$ hatalar için şiddet, ortaya çıkma ve saptama değerleri Tablo 1'den belirlenmiş ve her hata için RÖS değerleri hesaplanmıştır. Üretim sürecinde üründe meydana gelen hatalara ait RÖS değerlerinin hesaplandığ çizelge, Tablo 2'de verilmektedir.

Tablo 2. Üretim sürecinde üründe meydana gelene hatalara ait RÖS dĕgerlerinin hesaplandı̆̆ çizelge

\begin{tabular}{|c|c|c|c|c|c|}
\hline $\begin{array}{c}\text { Hata } \\
\text { No }\end{array}$ & Hata Adı & Şiddet (Ş) & $\begin{array}{c}\text { Ortaya Çıkma } \\
\text { (O) }\end{array}$ & $\begin{array}{l}\text { Saptama } \\
\text { (S) }\end{array}$ & $\begin{array}{l}\text { Risk Öncelik } \\
\text { Sayısı (RÖS) }\end{array}$ \\
\hline 1 & Kenar çatlakları & 7 & 3 & 3 & 63 \\
\hline 2 & Merdane izleri & 6 & 4 & 4 & 96 \\
\hline 3 & Boyuna çatlaklar & 8 & 4 & 4 & 128 \\
\hline 4 & Enine çatlaklar & 8 & 4 & 4 & 128 \\
\hline 5 & Katlanma, kıvrılma & 4 & 3 & 2 & 24 \\
\hline 6 & Çizikler, oyuklar & 5 & 3 & 2 & 30 \\
\hline 7 & Katlanmış kenarlar & 5 & 3 & 2 & 30 \\
\hline 8 & Katlanmalar & 6 & 3 & 2 & 36 \\
\hline 9 & Gevşek bobinler & 5 & 5 & 3 & 75 \\
\hline 10 & $\begin{array}{l}\text { Dağınık desen } \\
\text { görünümü }\end{array}$ & 7 & 4 & 3 & 84 \\
\hline 11 & Yara izleri & 7 & 2 & 3 & 42 \\
\hline 12 & Paslanma & 9 & 6 & 3 & 162 \\
\hline 13 & Bobin düzleşmesi & 8 & 4 & 3 & 96 \\
\hline 14 & Az miktarda dekapaj & 8 & 3 & 2 & 48 \\
\hline 15 & Çok miktarda dekapaj & 8 & 3 & 2 & 48 \\
\hline 16 & $\begin{array}{l}\text { Sac bobininin eksik } \\
\text { veya fazla etli olması }\end{array}$ & 5 & 5 & 3 & 75 \\
\hline 17 & Dalgalılık & 9 & 4 & 4 & 144 \\
\hline 18 & Taşlama izleri & 7 & 3 & 3 & 63 \\
\hline 19 & Siyah bant & 6 & 3 & 3 & 54 \\
\hline
\end{tabular}

Soğuk haddeleme ile sac malzeme üretim sürecinde, üründe meydana gelen hatalar için yapılan HTEA işleminden elde edilen RÖS değerlerine ait sıralama Şekil 3'de gösterilmektedir. Üründe meydana gelen hatalar değerlendirildiğinde paslanmanın ilk sırayı, sac malzeme yüzeyinde meydana gelen dalgalı görünümün ikinci sırayı, yine sac malzeme yüzeyinde meydana gelen enine ve boyuna çatlakların aynı RÖS değerine sahip olmasından dolayı bu iki hatanın da üçüncü sırayı aldığı görülmektedir. RÖS $>100$ olan hatalarda bu dört hatadan ibarettir ve üründe bu türden meydana gelebilecek olası hatalara karşı düzeltici önlemlerin alınması gerekmektedir.

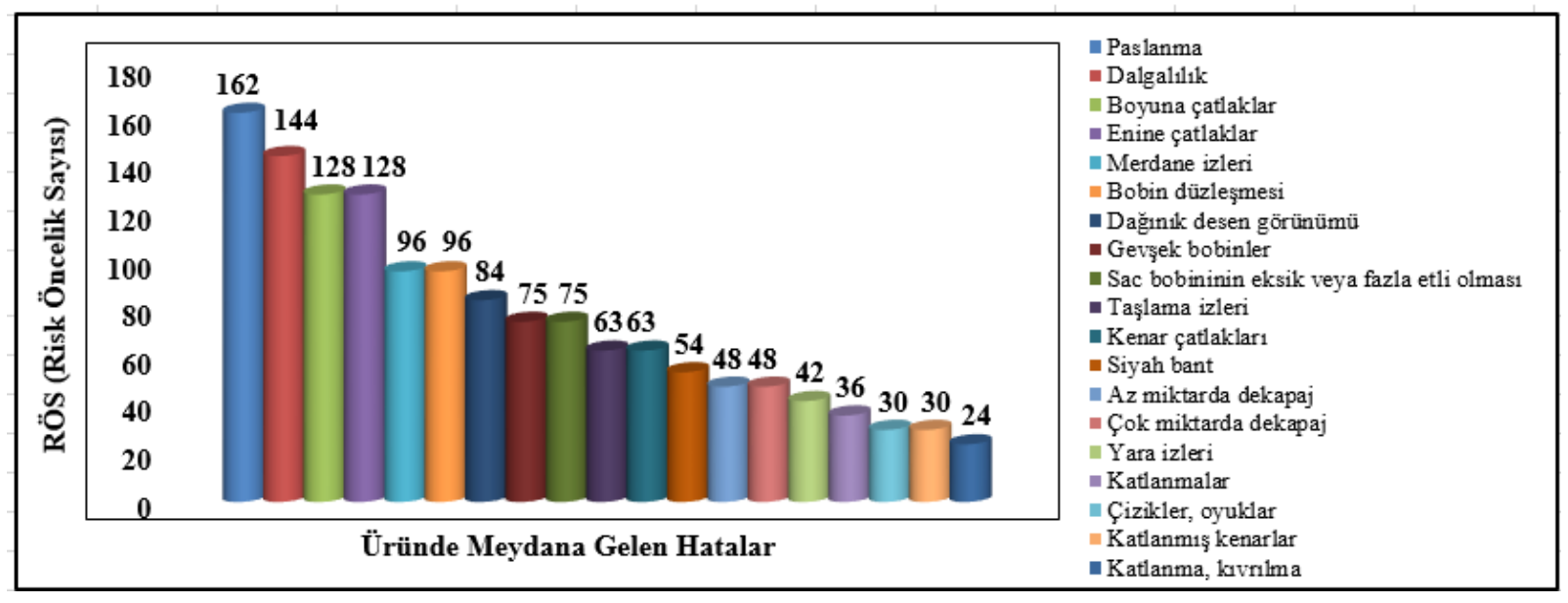

Şekil 3. HTEA işleminden elde edilen RÖS değerlerine ait sıralama

Sac malzeme yüzeyinde meydana gelebilecek paslanma hatalarına karşı sac malzemenin depolama süresinin uzun tutulmaması dolayısıyla ürünün satış potansiyeli değerlendirilerek üretim kararının verilmesi daha etkin şekilde bu sorunu ortadan kaldırmada etkili olabilir. Ayrıca depolama alanının neminin yüksek olması da bu hatanın oluşumunu hızlandıracak olmasından ötürü depolama alanının neminin çok yüksek olmamasına dikkat edilmesi de yine sorunun ortadan kaldırılmasında etkili bir önlem olacaktır. Sac malzemedeki dalgalı görünüme karşı ise destek merdaneleri, yağlayıcı 
malzemenin doğru kullanılması ve haddeye giren malzemenin şeklinin kontrolü ile bu hatanın azaltılmasında başarı sağlayacaktır. Sac malzemede meydana gelen enine ve boyuna çatlakların ise haddeleme işleminin malzeme dayanım sınırının altında gerilmelerin etkisi ile yapılması sayesinde bu hatalar da ortadan kaldırılacaktır.

\section{Sonuç}

$\mathrm{Bu}$ çalışmada soğuk haddeleme yöntemiyle üretilen sac malzemelerde üretim sürecinden kaynaklı meydana gelebilen ürün hataları belirlenmiş ve bu hatalara yönelik HTEA yöntemi kullanılarak risk öncelik sayıları (RÖS) tespit edilmiştir. Üretim sürecinde yüksek riske sahip (RÖS $>100$ ) hataların oluşmasını engellemek veya azaltabilmek amacıyla alınması gereken önlemlere yönelik birtakım önerilerde bulunulmuştur.

- Soğuk haddeleme yöntemiyle üretilen sac malzemelerde üretim sürecinden kaynaklı hatalar HTEA yöntemi ile analiz edildiğinde ilk sırayı paslanma, ikinci sırayı yüzeyde meydana gelen dalgalı görünüm ve üçüncü sırayı ise yüzeyde meydana gelen enine ve boyuna çatlakların aldığı görülmüştür.

- Soğuk haddeleme yöntemiyle üretilen sac malzemelerde üretim sürecinden kaynaklı hatalar HTEA yöntemi ile analiz edildiğinde RÖS $>100$ olan ürün hataları da paslanma, dalgalı görünüm ve enine ve boyuna çatlakların olduğu sonucuna varılmıştır.

- Soğuk haddeleme yöntemiyle üretilen sac malzemelerde üretim sürecinden kaynaklı hatalardan, paslanma problemine karşı depolama süresinin uzun tutulmaması ve depolama alanının neminin yüksek olmaması önerilmiştir. Dalgalı görünüme karşı ise destek merdaneleri, yağlayıcı malzemenin doğru kullanılması ve haddeye giren malzemenin şeklinin kontrolü ile hatanın azaltılabileceği önerilmiştir. Enine ve boyuna çatlakların ise haddeleme işleminin malzeme dayanım sınırı altındaki gerilmeler altında haddelenmesi sonucunda ortadan kaldırılacağı sonucuna varılmıştır.

\section{Kaynakça}

Andrei, C., Bogdan, M., Georgian, N., Ionut, P., \& Zorica, B. (2010). Cold rolling shape defects of stainless steel wide strips. In European Conference of Chemical Engineering, 10, 154-158.

Anita, T., \& Singh, L. (2018) "Study of rolling mill defects: A survey approach," International Journal of Research Aeronautical and Mechanical Engineering, 6(9), 170-175.

Colli, A. (2015). Failure mode and effect analysis for photovoltaic systems. Renewable and Sustainable Energy Reviews, 50, 804809.

Değirmenci, H. (2006) “Çelik sacların mekanik özelliklerinde ortaya çıkan değişimler ve nedenleri ile bunların şekillendirme prosesi üzerindeki etkileri," Yüksek Lisans Tezi, Yıldız Teknik Üniversitesi Fen Bilimleri Enstitüsü, İstanbul, Türkiye.

Dwianda, Y. (2021). Failure mode and effect analysis (FMEA) of pneumatic system of cnc milling machine. Journal Of Ocean, Mechanical and Aerospace-Science and Engineering, 65(1), 1418.
Erdemir T.A.Ş. yassı ürün kataloğu (2021). https://www.erdemir.com.tr/Sites/1/upload/files/yassi-urunkatalogu-eylul-2020-tr-4677.pdf

Groover, M. P. (2020). Fundamentals of modern manufacturing: materials, processes, and systems. John Wiley \& Sons.

Kaya, S. Ş., \& Alaykıran, K. (2019). Hata türü ve etkileri analizi ve döküm sektöründe bir uygulama. Necmettin Erbakan Üniversitesi Fen ve Mühendislik Bilimleri Dergisi, 1(2), 76-89.

Mhetre, R. S., \& Dhake, R. J. (2012). Using failure mode effect analysis in precision sheet metal parts manufacturing company. International Journal of Applied Sciences and Engineering Research, 1(2), 302-311.

Nguyen, T. L., Shu, M. H., \& Hsu, B. M. (2016). Extended FMEA for sustainable manufacturing: An empirical study in the nonwoven fabrics industry. Sustainability, 8(9), 939.

Özakın, B. (2021). "Temper haddelemede mekanik özellik-yüzey pürüzlendirme ilişkisinin incelenmesi," Doktora Tezi, Ondokuz Mayıs Üniversitesi Lisansüstü Eğitim Enstitüsü, Samsun, Türkiye.

Özakın, B., \& Kurgan, N. (2019). Temper haddelemede pürüzlülük transferini etkileyen parametrelerin incelenmesine yönelik bir derleme çalışması. International Periodical of Recent Technologies in Applied Engineering, 1(2), 67-78.

Parsana, T. S., \& Patel, M. T. (2014). A case study: A process FMEA tool to enhance quality and efficiency of manufacturing industry. Bonfring International Journal of Industrial Engineering and Management Science, 4(3), 145-152.

Pillay, A., \& Wang, J. (2003). Modified failure mode and effects analysis using approximate reasoning. Reliability Engineering \& System Safety, 79(1), 69-85.

Salvi, R. K., \& Jindal, S. (2017). FMEA to enhance quality and efficiency of CNC machines: a case study in valve manufacturing industry. Industrial Engineering Journal, 10(5), 13-19.

Sharma, A., \& Yadava, V. (2018). Experimental analysis of Nd-YAG laser cutting of sheet materials-A review. Optics \& Laser Technology, 98, 264-280.

Sönmez, Y., \& Unğan, M. C. (2016). Hata türü etkileri analizi ve otomotiv parçaları üretiminde bir uygulama. Işsletme Bilimi Dergisi, 5(2), 217-245.

Stamatis, D. H. (2003). Failure mode and effect analysis: FMEA from theory to execution. Newyork, USA: Quality Press.

Steel JRV. website. (2021). https://www.steeljrv.com/

Suresh, A., Pramod, V. K., \& Pramod, V. R. (2017). Failure mode effect analysis in a frying pan manufacturing industry. International Research Journal of Engineering and Technology (IRJET), 4(8), 1183-1189.

Şimşir, F., Demir, H. İ., \& Azdemir, S. (2018). Demir çelik sektöründe hibrid DEMATEL ve TOPSİS-ELECTRE yöntemleri ile hata türleri ve etkileri analizi. Academic Platform Journal of Engineering and Science, 6(3), 22-34.

TI Strip website. (2021). http://www.tistrip.be/Front/c1317/Production-Process.aspx

Vinodh, S., \& Santhosh, D. (2012). Application of FMEA to an automotive leaf spring manufacturing organization. The TQM Journal.

Wu, Z., Liu, W., \& Nie, W. (2021). Literature review and prospect of the development and application of FMEA in manufacturing industry. The International Journal of Advanced Manufacturing Technology, 1-28.

Yousefi, S., Alizadeh, A., Hayati, J., \& Baghery, M. (2018). HSE risk prioritization using robust DEA-FMEA approach with undesirable outputs: a study of automotive parts industry in Iran. Safety Science, 102, 144-158. 